\title{
More Than Socially Embedded: The Distinctive Character of 'Communal Tenure' Regimes in South Africa and its Implications for Land Policy
}

\author{
BEN COUSINS
}

This article analyzes debates over tenure reform policy in post-apartheid South Africa, with a particular focus on the controversial Communal Land Rights Act of 2004. Land tenure systems in the 'communal areas' of South Africa are described as dynamic and evolving regimes within which a number of important commonalities and continuities over time are observable. Key underlying principles of pre-colonial land relations are identified, which informed the adaptation and modification of tenure regimes in the colonial era and under policies of segregation and apartheid, and continue to do so today. Exploring the policy implications of this analysis, the article suggests that alternative approaches to that embodied in the Communal Land Rights Act are required. The most appropriate approach is to make socially legitimate occupation and use rights, as they are currently held and practised, the point of departure for both their recognition in law and for the design of institutional frameworks for administering land.

Keywords: tenure reform, Communal Land Rights Act, communal tenure, land rights, traditional authority, South Africa, Africa

\section{INTRODUCTION}

Controversies over land tenure reform in post-apartheid South Africa resonate strongly with those raging elsewhere in Africa. This article focuses on a recent South African law, the Communal Land Rights Act of 2004, and relates debates around the Act to long standing arguments on the nature of land rights and authority over land in Africa, and on state policies to reform 'customary' land

Ben Cousins, Programme for Land and Agrarian Studies, University of the Western Cape, Private Bag X17, Bellville, RSA. e-mail: bcousins@uwc.ac.za

An earlier version of this paper was co-authored with my long-term collaborator, Aninka Claassens, and presented as a keynote address to a conference on 'At the frontier of land issues: social embeddedness of rights and public policy', Montpellier, 17-19 May 2006. This version draws heavily on the insights of Claassens, whose comments are gratefully acknowledged. Many thanks also to the conference paper's discussants, Franz van Benda-Beckmann and Etienne le Roy, for their comments, and to Henry Bernstein for his critical remarks and useful suggestions. 


\section{Ben Cousins}

tenure. Given that compulsory and systematic individual titling is no longer seen as an appropriate policy in African contexts by most policy analysts, the central issue in tenure reform in many parts of Africa (and elsewhere) is how to recognize and secure land rights that are clearly distinct from 'Western-legal'" forms of private property but cannot be characterized as 'traditional' or 'pre-colonial', given the impacts of both colonial policies and of past and current processes of rapid social change.

The policy challenge is to decide what kinds of rights, held by which categories of claimants, should be secured through tenure reform, and in what manner, in ways that will not merely 'add to possibilities of manipulation and confusion' (Shipton and Goheen 1992, 318). The difficulties are underlined by consideration of the record to date, in which reform efforts have not taken sufficiently into account the reality of how tenure regimes operate in practice, leading to a variety of unintended consequences (Shipton 1988; Berry 1993). Securing the land rights of women and other vulnerable categories and interest groups has proved particularly difficult. The analytical challenge is to characterize complex and dynamic realities using appropriate concepts and theories, which might inform the design of policies and laws.

Another key issue is authority over land matters and the design of appropriate institutional frameworks for land administration. Power relations are key to understanding how tenure regimes work in practice, since 'struggles over property are as much about the scope and constitution of authority as about access to resources' (Lund 2002, 11). In particular, the powers and functions of 'customary authorities' in relation to land are highly controversial and widely debated. A particularly contentious issue, which the South African case clearly illustrates, is the demarcation of the jurisdictional boundaries of 'customary authorities', which has important implications for how land rights are defined and administered as well as for broader questions of local governance (see Lentz 2006 for an instructive Ghanaian case).

I argue in this article that the character of land tenure regimes in the 'communal areas' of South Africa are dynamic and evolving regimes within which a number of important commonalities and continuities over time are observable in many, but not all, circumstances. Some key underlying principles of pre-colonial land relations are identified, which informed adaptations of tenure regimes in the colonial era and in the subsequent period when policies of segregation and apartheid were pursued, and continue to do so in many areas today. Exploring the policy implications of this analysis, I suggest that the most appropriate approach to tenure reform in South Africa is to make socially legitimate occupation and use rights, as they are currently held and practised, the point of departure for both their recognition in law and for the design of institutional frameworks for mediating competing claims and administering land.

1 Daley and Hobley $(2005,8)$ suggest this useful term for dominant notions of private property.

(C) 2007 The Author.

Journal compilation (c) 2007 Blackwell Publishing Ltd, Henry Bernstein and Terence J. Byres. Journal of Agrarian Change, Vol. 7 No. 3, July 2007, pp. 281-315. 


\section{TENURE REFORM IN POST-APARTHEID SOUTH AFRICA}

Contemporary forms of 'customary' or 'communal' land tenure in South Africa can be understood only in the context of a centuries-old history of land dispossession and state regulation, together with a variety of local responses, ranging from high-profile rebellions to 'hidden struggles' (Beinart and Bundy 1987) that shaped the outcomes of these interventions to a degree. This history has involved major modification and adaptation of indigenous land regimes, but seldom their complete destruction and replacement. Conquest and settlement in the colonial period, followed by twentieth-century policies of segregation and apartheid, saw white settlers and their heirs take possession of most of the land surface of South Africa. State policies attempted to reconfigure the livelihood and land tenure systems of the indigenous populations in ways that served the interests of the dominant classes. African 'reserves' were created as a way to contain resistance and to facilitate the supply of cheap labour for the emerging capitalist economy. They also functioned to lower the cost of colonial administration through a system of indirect rule, within which traditional leaders undertook local administration on behalf of the state - often in a highly authoritarian manner, termed 'decentralized despotism' by Mamdani (1996).

The large-scale dispossession of land that took place means that programmes of land redistribution and restitution are the key focus of South African land reform policies in the post-apartheid era. The third leg of land policy is tenure reform, which aims to secure the land rights of farm workers and labour tenants living on privately-owned large-scale commercial farms and of residents in the 'communal areas', or former reserves. These constitute around 13 per cent of the land area of the country, but are home to a large proportion of the country's population - perhaps 20 million, or around 43 per cent of the total.

There is widespread overcrowding and forced overlapping of rights in these areas as a result of a history of forced removals and evictions of black South Africans from white-owned land, and uncertainty as to the legal status, content and strength of these rights. Administration by traditional leaders often involves corruption in relation to land (Levin and Mkhabela 1997; Ntsebeza 1999; Claassens 2001). The land administration system in many 'communal' areas is now near collapse. Permission to Occupy certificates (PTOs) may or may not be issued to occupiers of land, procedures to allocate land vary widely and are often ad hoc, and registers of rights holders are seldom kept up to date (Lahiff and Aphane 2000; Turner 1999; MacIntosh, Xaba and Associates 1998). Lack of clarity on land rights constrains infrastructure and service provision, and there are tensions between local government bodies and traditional authorities over the allocation of land for development projects (e.g. housing, irrigation schemes, business centres and tourist infrastructure - see Peires 2000). Women's land rights are more insecure than those of men, and are often seen as 'secondary' in character, given that women's access to land is obtained only via their husbands or other male relatives (Meer 1997).

(C) 2007 The Author.

Journal compilation @ 2007 Blackwell Publishing Ltd, Henry Bernstein and Terence J. Byres. Journal of Agrarian Change, Vol. 7 No. 3, July 2007, pp. 281-315. 


\section{Ben Cousins}

In some areas the existing regimes appear reasonably stable, with most occupants of communal land experiencing de facto security of tenure (Adams et al. 2000; Turner 1999). On the other hand, these systems are also under increasingly severe strain as a result of overcrowding, weak administration, abuses by traditional leaders, tension over common property resource use, and lack of clarity over the roles and responsibilities of traditional authorities and local government bodies. This can lead to heated debates at the local level about how land rights and administration should be reformed (Claassens 2003). The key problem that tenure reform policy sets out to address is the underlying legal insecurity of land tenure rights, which surfaces most clearly when development projects are planned and implemented (Adams et al. 2000; Kepe 2001).

Tenure reform in South A frica is seen a constitutional imperative. Section 25 (6) of the Bill of Rights in the 1996 Constitution asserts that:

A person or community whose tenure of land is legally insecure as a result of past racially discriminatory laws or practices is entitled, to the extent provide by an Act of Parliament, either to tenure which is legally secure or to comparable redress.

The South African White Paper on Land Policy (DLA 1997, 57-8) sets out an approach that seeks to give effect to this constitutional right. Land tenure policies must 'move towards rights and away from permits' and aim to build a 'unitary non-racial system of land rights for all South Africans'. It must 'allow people to choose the tenure system which is appropriate to their circumstances' (including both group and individual ownership), but these 'must be consistent with the Constitution's commitment to basic human rights and equality'. In order to secure tenure, 'a rights based approach has been adopted' which must 'recognize and accommodate the de facto vested interests which exist on the ground', including legal rights but also 'interests which have come to exist without formal legal recognition'. Where overlapping and conflicting rights cannot be reconciled within one area, additional land will be required to relieve land shortages, to ensure that strengthening the rights of some does not lead to the eviction of others. In the White Paper individual titling was accepted as one possible option, but the greatest emphasis was placed on a democratic reform of collective systems, within which members will have the power to choose the structure which represents them in decisions pertaining to the day to day management of the land and all issues relating to member's access to the land asset' (DLA 1997, 63).

Within the broad category of 'communal tenure', a wide range of situations can be identified. For example, in some areas occupation has been continuous over long periods of time, and people were not subject to forced removals. In other regions, by contrast, a great deal of population relocation occurred, laying the basis for a large number of land restitution claims. In some areas rural land purchased for occupation by black people by the South African Development Trust (SADT) after 1936 was intensively administered by state bureaucrats who monitored and enforced the PTO system (Cross 1992). Some parts of the 
Eastern Cape were subject to colonial policies aimed at individualizing land tenure, but in many of these elements of a 'communal' system persisted or reemerged over time (Kingwill 1996). Land rights in small-scale irrigation schemes often took the form of a variant of the PTO system but involved additional complexities (Lahiff 2000), and a degree of de facto individualization is occurring in 'communal areas' adjacent to towns and cities, where informal land markets have emerged (Cross 1992; Royston 2004). This diversity poses huge challenges to policy.

\section{THE LAND RIGHTS BILL OF 1999}

Government's initial approach to the question of how to give full legal recognition to the rights of people in 'communal' areas was based on a paradigm of transferring ownership from the state to groups or individuals. However, experience in a number of test cases in 1997 and 1998 revealed inherent difficulties (Claassens $2000,253-4)$. One was how to define the 'unit of ownership': should land be transferred to 'tribes', often consisting of hundreds of thousands of people, or to a population under a chief and a designated Tribal Authority, or to smaller units such as wards or villages? Vesting land ownership in a larger group could make it difficult for smaller groups to make meaningful decisions about land within their own localities; on the other hand, vesting rights in members at the local level might deny some rights inherent in the larger group of which they form a part, such as access to shared common property resources. Another lesson was that investigation and consultation with prospective rights holders was resourceintensive and time-consuming. Test cases also showed that the prospect of the transfer of private ownership raised the stakes in tenure disputes and triggered major tensions and conflicts between competing interest groups.

As a result of these difficulties, policy thinking moved towards the creation of 'statutory' rights which would be secure in law but would not entail the transfer of title. A Land Rights Bill (LRB) drafted in 1998/99 ${ }^{2}$ created a category of protected rights for which the majority of those occupying land in the former 'homelands' would qualify (Claassens 2000, 255). Most 'communal' land is registered as the property of the state. The LRB envisaged clear statutory limitations on the state's rights in respect of this land. It proposed the vesting of occupation, use, benefit and decision-making rights in a class of 'protected' rights holders. Critically, the Bill provided that the holders of protected rights could not be deprived of land without their consent, except by expropriation, for example when land is required for public purposes, and with compensation. The Minister of Land Affairs would continue to be the nominal owner of the land, but with strictly delimited powers. Protected rights would vest in the individuals who use, occupy or have access to land, but in group systems protected rights would be relative to those shared with other members; individual

2 I was a member of the team that drafted the Land Rights Bill. This has no doubt influenced my assessment of the Communal Land Rights Act. 
rights would thus be relative to 'group rules', as decided upon by the majority of members. This in turn would require the definition of the boundaries of the group - a key difficulty, as pointed out above, for the original 'transfer of ownership' paradigm. The solution proposed in the LRB was as follows:

'boundaries' must be seen as flexible. In other words, the boundary of the group would be determined with reference to who (which group of people) is affected by the particular decision. Thus, if the decision is about a change in grazing practice then the people affected by the change must be consulted, not the entire 'tribe'. (Claassens 2000, 255)

Statutory protected rights would secure occupation and use without having to first resolve disputes over the precise nature and extent of these rights. The minimum content of protected rights was set out in the LRB: it included access, occupation, use and benefit. The rights could be bequeathed and, potentially, transacted and mortgaged. Beyond its basic minimum content, the LRB enabled a process of group decision-making with regard to augmenting the content of protected rights, in particular in respect of the ability to transact and develop land. This might result, for example, in a decision allowing internal sales of the right to homestead plots to 'community' members in a particular area, but limitations on transactions with outsiders.

The LRB proposed that people had the right to choose which local institution would manage and administer land rights on their behalf. Agreed group rules would have to provide 'bottom line' protections for members, consistent with constitutional principles of democracy, equality and due process, and rights holders and local institutions would be supported by a Land Rights Officer based in each district. Where rights are overlapping and contested due to forced removals and evictions in the past, confirmation of rights would only take place after a rights enquiry, with government providing incentives to stakeholders to negotiate acceptable solutions, mainly in the form of additional land to relieve overcrowding.

The draft LRB never saw the light of day. In June 1999 a new Minister of Agriculture and Land Affairs took office, ${ }^{3}$ and the LRB was set aside. In her view the approach adopted was too complex and would be too costly to implement. She was in favour of a law that transferred title of state land to 'tribes' (or 'traditional communities'), allowed traditional leaders to administer land, and did not require high levels of institutional support to rights holders. Following several false starts, a Communal Lands Rights Bill was drafted between 2001 and 2003 and eventually enacted in early 2004 (for a detailed account of this process see Cousins and Claassens 2004). Three years on, implementation has yet to begin, in part because of inadequate departmental capacity, in part because of a pending constitutional challenge to the Act.

3 Ms Thoko Didiza, now Minister of Public Works.

(C) 2007 The Author.

Journal compilation (c) 2007 Blackwell Publishing Ltd, Henry Bernstein and Terence J. Byres. Journal of Agrarian Change, Vol. 7 No. 3, July 2007, pp. 281-315. 


\section{THE COMMUNAL LAND RIGHTS ACT OF 2004}

The Communal Land Rights Act (CLRA) extends private ownership of land to rural 'communities'. Within areas of 'communally owned' land it establishes a register of 'new order rights' vested in individuals. It also provides for a land administration committee to exert ownership powers on behalf of the 'community' it represents, and allows 'tribal councils' to act as such committees (Republic of South Africa 2004).

\section{Transfer of Ownership}

The CLRA transfers title of communal land from the state to a 'community', which must register its rules before it can be recognized as a 'juristic personality' legally capable of owning land. Individual members of this community are issued with a Deed of Communal Land Right, which can be upgraded to a freehold title if the community agrees. The Minister must make a determination on whether or not 'old order rights' (i.e. communal land rights derived from past laws and practices, including 'customary law and usage') should be confirmed and converted into 'new order rights', and must determine the nature and extent of such rights. New order rights can be registered in the name of a 'community' or a person, but where title is transferred to a 'community' the individual new order rights are not equivalent to (individual) title. The minimum content of new order rights is not set out in the Act.

Before transfer of ownership can occur the boundaries of 'community' land must be surveyed and registered. Also a rights enquiry must take place, to investigate the nature and extent of existing rights and interests in land (including competing and conflicting rights), options for securing such rights, measures to ensure gender equality, and spatial planning and land use issues. The Minister will then determine the location and extent of the land to be transferred, and whether or not the whole of an area or some portion of it should be transferred to the 'community'. A part of the land may be subdivided and transferred to individuals, and portions may be reserved to the state.

The CLRA requires that community rules are drawn up before any transfer of land, to regulate the administration and use of communal land. The Act does not specify the process whereby such rules are to be drawn up and agreed, nor its timing (e.g. whether or not the drawing up of such rules precedes the establishment of a land administration committee).

\section{Definition of 'Community' and the Vesting of Rights}

The CLRA vests ownership in the 'community', defined as 'a group of people whose rights to land are derived from shared rules determining access to land held in common by such group'. Senior government officials have stated in parliament that they view the population of areas under the jurisdiction of tribal 
authorities, headed by chiefs, as the relevant 'communities' ${ }^{4}$ Land administration committees represent the 'community' and take decisions on its behalf. Tribal authority boundaries are often contentious, many having been demarcated during the implementation of the Bantu Authorities Act early in the apartheid era.

\section{Gender Equality}

The CLRA contains a general provision that a woman is entitled to the same tenure rights as a man, and no laws, rules or practices may discriminate on the grounds of gender. It provides for the Minister to confer a 'new order right' on a woman, even where 'old order rights' such as Permission to Occupy certificates (PTOs) were vested only in men. New order rights are deemed to be held jointly by all spouses in a marriage, and must be registered in all their names. Adult female members of households who use land, but who are not spouses, are not provided for. The CLRA also requires that at least one third of the membership of a land administration committee be female.

\section{Constitution of Land Administration Bodies}

In the CLRA, a 'community' which applies for title must establish a land administration committee, which 'represents a community owning communal land', and has the powers and duties conferred on it by the CLRA and by the rules of such a 'community'. It must allocate land rights, maintain records of rights and transactions, assist in dispute resolution, and liaise with local government bodies in relation to planning and development and other land administration functions.

Where they exist, traditional councils established under the Traditional Leadership and Governance Framework Act (TLGFA) of 2003 'may' exercise the powers and functions of such land administration committees. ${ }^{5}$ There are competing interpretations of this provision. In one view, it allows for choice on the part of rights holders as to which local body will perform land administration functions, but another view holds that the word 'may' is permissive only, enabling a traditional council to exercise the powers of a land administration committee, rather than creating a choice for rights holders. The Act does not explicitly provide for choice, for example by setting out procedures and oversight mechanisms, which suggests that the latter interpretation is correct.

4 Dr Sipho Sibanda of the Department of Land Affairs, addressing a meeting of the Portfolio Committee on Agriculture and Land Affairs, House of Assembly, 26 January 2004.

5 Section 21 (2) of the CLRA states that 'If a community has a recognised traditional council, the powers and duties of the land administration committee of such community may be exercised and performed by such council'. The TLGFA allows existing Tribal Authorities to be deemed traditional councils if they 'transform' themselves within one year, after which time 40 per cent of members must be elected and 30 per cent must be women. 


\section{Determination of Group Boundaries}

The CLRA provides for the Minister to make a determination of 'community' boundaries, on the basis of the land rights enquiry. Transfer of title involves demarcating and surveying the boundaries of the 'community' that will become the legal owner of communal land, as well as of internal boundaries in terms of a 'communal general plan'. As described above, one interpretation of the Act is that 'communities' will coincide with the population currently under tribal authorities, when these are reconstituted as 'traditional councils'. These areas typically have populations of between 10,000 and 20,000, and tribal authorities and the chiefs that head them have jurisdiction over a great many wards and villages, under the authority of sub-chiefs, headmen or sub-headmen. They are thus aggregates of a large number of smaller 'communities'. The fact that many groups and individuals now fall under the jurisdiction of chiefs and tribal authorities that they had had no previous connection to, and whose authority they now contest, is not acknowledged.

\section{Decision-making in Relation to Land}

The CLRA establishes land administration committees to make key decisions and exert ownership powers on behalf of the 'community'. It does not require land administration committees to consult with the 'community' members it represents in relation to major decisions such as disposal of land or of rights in such land. The only requirement in such a case is ratification of a decision by a provincial Land Rights Board. The CLRA does not set out procedures for decisionmaking (e.g. in relation to the adoption of 'community' rules or the holding of a land rights enquiry), but states that rights enquiries must be open and transparent, and that decisions must be informed and democratic.

\section{DEBATING THE COMMUNAL LAND RIGHTS ACT}

The key policy decisions embodied in the CLRA are to transfer private ownership to 'communities', after a rights enquiry and detailed Ministerial determinations. Deeds of Communal Land Right, the form in which the "new order rights' of community members are to be registered, are secondary rights of occupation and use, subordinate to group ownership. Land administration committees will have powers akin to those of owners. This approach has been widely criticized and was debated at length in parliamentary consultations before the law was enacted, with the powers of traditional councils over land being one of the most controversial issues (Cousins and Claassens 2004; Cousins 2005; Murray 2004).

Both the draft law and presentations to parliament by senior officials made it clear that 'communities' would be defined as those people living within tribal authority boundaries, that traditional councils would be recognized as land administration committees and that rights holders would have no effective choice on this matter. These provisions were greeted with dismay by community 
groups and NGOs, which saw this as undermining fundamental democratic rights. Some observers suggested that the last-minute inclusion of this provision in the draft law of 2003, just days before parliamentary consultations were to begin, was the result of a back-room political deal with the traditional leader lobby in the run-up to a national election (Govender 2004; Murray 2004). In response to the overwhelming rejection of these provisions by the majority of parliamentary submissions, the draft law was substantially amended before its approval in 2004, and the Act, as outlined above, is now somewhat ambiguous about whether or not rights holders have a choice in relation to how a land administration committee is to be constituted (see above). This aspect remains highly controversial.

In April 2006 four rural groupings, self-identified as 'communities', initiated a constitutional challenge to the Act, with the assistance of the Legal Resources Centre and associated lawyers. The question of whether or not traditional councils will act as land administration committees wherever they exist is one of the key issues in the challenge. In all four cases a history of interference with the land rights of groups and individuals by chiefs informs residents' anxiety that implementation of the CLRA will result in control over land being vested in traditional councils ('transformed' tribal authorities) at the expense of the rights of current land holders. In two of the four cases the jurisdiction of tribal authorities over subordinate groups ('communities') is deeply contested.

Legal papers also assert that the CLRA is unconstitutional because the nature and content of 'new order rights' are not clearly defined, and the Minister of Land Affairs is given wide and sweeping powers to determine these rights on a discretionary basis. It is argued that no clear criteria to guide the Minister's decisions are provided by the Act, and few opportunities to participate in making these crucial decisions, or to challenge them, are created. A critical omission is the lack of consultation with rights holders on whether or not they desire a transfer of title.

Some critiques of the CLRA (Claassens 2005; Cousins 2005) suggest that the Act entrenches particular versions of 'customary' land tenure that resulted from colonial and apartheid policies, and that this will have the effect of undermining rather than securing land rights. In many pre-colonial tenure systems, it is argued, land rights were derived in the first instance from accepted membership of a group. Decisions in relation to residential and arable land (including the transfer of rights to others through inheritance, bequeathing, lending, sharecropping or sale) were made primarily at a household level. Security of rights derived from a relative balance of power between authority structures and rights holders. The CLRA shifts the balance of power away from individuals and households towards the group and its authority structures, on the one hand, and towards the Minister (as advised by officials), on the other. Ownership at the level of the traditional council/chieftaincy will 'trump' the rights that exist at lower levels, such as household and individual rights to residential and arable land.

A second argument is that the transfer of ownership of communal land from the state to 'communities', with the requirement that outer boundaries be surveyed 
and registered, conflicts with the nested and overlapping character of land rights in 'communal areas'. As a result, implementation of the CLRA is likely to exacerbate existing tensions and disputes over boundaries (including disputes with sub-groups placed under the jurisdiction of chiefs under apartheid), and generate new tensions in areas which are currently relatively stable (Cousins 2005).

In relation to gender equality, it has been suggested that the CLRA undermines the tenure rights of female household members who occupy and use land other than as wives, such as mothers and divorced or unmarried adult sisters. In addition, it is unclear what land rights can be claimed by women who are divorcees at the time that a determination is made by the Minister, since they will no longer be married and thus cannot be deemed to be the joint holder of an 'old order right' (Claassens 2005).

Underlying these debates over the CLRA (and the Traditional Leadership and Governance Framework Act) are competing views of the relationship between custom and democracy. Some emphasize tensions between the values, practices and political identities associated with 'customary systems' and liberal democracy (Comaroff and Comaroff 2006), but others see them as potentially reconcilable (Nhlapo 1995). Government defends the approach adopted in the CLRA as consistent with both the nature of customary land tenure and democratic rights (Sibanda 2004). Some critics see the CLRA and the TLGFA as a complete betrayal of democracy, and assert that attempts to reconcile custom and democratic rights are inherently contradictory (Ntsebeza 2004).

South African debates echo those in the wider African context (see further below). On one hand, recent years have seen a marked emphasis in both advocacy and state policy on recognition of 'customary' law and institutions, together with the idea of devolving responsibility for land management to local institutions. This is in large part a reaction to the evident failures of individual land titling in countries such as Kenya. On the other hand, this policy stance has been criticized for 'positing a panacea' (Daley and Hobley 2005, 34) that fails to adequately acknowledge socio-economic differentiation and the realities of local politics and power relations, within which 'the democratic substance of village governments ... is often unclear' (Daley 2005b). Disquiet over the manipulation of ideas about the 'customary' by powerful men informs Whitehead and Tsikata's view (2003, 103) that there are 'too many hostages to fortune in the language of the customary at a national level for it to spearhead democratic reforms and resistance to centralized and elite-serving state power'.

In relation to South African tenure reform, I suggest that an alternative approach to the CLRA is both necessary and feasible, and that this alternative is not individual titling. Policy must take cognisance of the complexities and realities of current regimes of claims, rights and their governance, i.e. how 'actuallyexisting' tenure systems operate in practice. It must then aim to build upon those characteristics that provide an appropriate basis for securing land rights and democratizing land administration, and at the same time address problematic features of current systems such as gender inequality. The next section attempts to identify the relevant characteristics, through a review of some of the literature 


\section{Ben Cousins}

on land tenure in South Africa (and, where relevant, elsewhere in Africa) from the pre-colonial era to the present.

\section{ANALYZING 'COMMUNAL' LAND TENURE IN SOUTH AFRICA: UNDERLYING PRINCIPLES, CONTINUITY AND CHANGE}

'Western-legal' regimes of private property are historically specific and the concepts and terms associated with them must be used with caution. Administrators and anthropologists in the early colonial period recognized that legal concepts and language derived from European systems of law would not be appropriate in African (and other) contexts, but did not always agree on which concepts to use in their place (Bohannon 1963; Gluckman 1965). According to Biebuyck $(1963,52)$ 'common general formulae like . . . ultimate or sovereign rights, rights of allocation or of control, or rigid oppositions between ownership, possession, use and usufruct . . . have often obscured understanding of the scope and nature of rights and claims relating to the land'.

Okoth-Ogendo (1989) does not rely on European legal doctrine in his persuasive analysis of the nature of property rights in Africa. In his view a 'right' signifies a power that society allocates to its members to execute a range of functions in respect of any given subject matter. Where that power amounts to exclusive control one can talk of 'ownership' of 'private property', but it is not essential that power and exclusivity of control coincide in this manner. Access to this power (i.e. a 'right') and its control are distinct, and there are diverse social and cultural rules and vocabularies for defining access and control.

In Africa, according to Okoth-Ogendo, land rights tend to be attached to membership of some unit of production; are specific to a resource management or production function; and are maintained through active participation in the processes of production and reproduction at particular levels of social organization. Control of such access is attached to 'sovereignty' (in its non-proprietary sense) and vested in political authority over different levels of social organization and units of production. Control occurs primarily for the purposes of guaranteeing access to land for production purposes. In these land tenure regimes there is no coincidence of access and control, and property does not involve the vesting of the full complement of power over land that is possible (i.e. private property). Variations in power (i.e. rights) derive from social relations, not the market. Control is exercised through members of the units of production; control is not simply the product of 'political superordination' (Okoth-Ogendo 1989, 11).

I make use of Okoth-Ogendo's conceptual framework in tracing patterns of continuity and change in land tenure regimes in South Africa from the precolonial era through to the present. ${ }^{6}$ I concur broadly with his view that indigenous norms and structures' in relation to property have demonstrated great resilience in the face of colonial and post-colonial policies of 'subversion, expropriation

6 The main focus in this review is the South African literature, but reference is made, where relevant, to materials from the wider African context. 
and suppression' (Okoth-Ogendo 2002, 10). Building on this insight, I argue that some key underlying principles and characteristics can often be observed in land tenure regimes over time. These are briefly described here, and numbered for ease of reference in the discussion that follows, which provides concrete illustrations.

1. Land and resource rights are directly embedded in a range of social relationships and units, including households and kinship networks; the relevant social identities are often multiple, overlapping and therefore 'nested' or layered in character (e.g. individual rights within households, households within kinship networks, kinship networks within wider 'communities').

2. Rights are derived primarily from accepted membership of a social unit, and can be acquired via birth, affiliation or allegiance to a group and its political authority, or transactions of various kinds (including gifts, loans and purchases).

3. Land and resource rights include both strong individual and family rights to residential and arable land and access to a range of common property resources such as grazing, forests and water. They are thus both 'communal' and 'individual' in character.

4. Access to land (through defined rights) is distinct from control of land (through systems of authority and administration). Control is concerned with guaranteeing access and enforcing rights, regulating the use of common property resources, overseeing mechanisms for redistributing access and resolving disputes over claims to land. It is often located within a hierarchy of nested systems of authority, with many functions located at local or 'lower' levels.

5. Social, political and resource boundaries, while often relatively stable, are also flexible and negotiable to an important extent; this flows in part from the nested character of social identities, rights and authority structures.

I am aware of the dangers of 'abstracting institutions from . . . specific historical circumstances' (Kuper 1997, 74) and of Moore's (1998, 39) critique of Etienne le Roy's attempt to define and model African land relations, which she suggests is essentialist and reductionist and 'at quite a distance from the multiple, shifting, permutating, recombining practices of rural Africa'. Nevertheless, my review of the literature suggests that the general principles listed above can often be discerned, embodied within a range of contextually specific land tenure regimes, both in the past and today. The extent to which, and ways in which, these principles are found in 'actually-existing' land tenure regimes are variable, given complex histories of state interventions and diverse, adaptive responses to these interventions. In specific cases some of these characteristics may be absent altogether. Where these characteristics are present, however, property regimes remain distinct from 'Western-legal' forms of private property, which is why they present such a challenge to tenure reform policy.

\section{The Pre-Colonial Era}

Anthropologists undertaking fieldwork in the early to mid-twentieth century attempted to identify the general characteristics of African land tenure in the 


\section{Ben Cousins}

pre-colonial era. Biebuyck (1963, 52-64) provides a useful summary: land was plentiful and exploitation of resources was generally extensive; land was essential for livelihoods but had little exchange value; land was 'vested in groups' (chiefdoms, villages, lineages or other social groupings) represented by their chiefs, elders and/or councils. There was 'a close relationship between features of social and political organisation and principles of land tenure' (ibid., 52) (principle 1).

All members of a group had rights of access to land, derived from membership in the group, and in some cases from allegiance to a political authority such as a chief (principle 2). Rights in land could also be obtained through marriage, migration, friendship and formal transfer. The exercise of any right was always limited by obligations and counterbalanced by others' rights and privileges. Individual security was great, provided the necessary respect for the ethical code of the group was maintained. Effective use and appropriation were generally required for the maintenance of individual and family rights in a particular piece of land. Often a number of individuals, households or larger social units exercised rights and claims in the same piece of land. Land tenure was everywhere both 'communal' and 'individual' (ibid., 54-5) or what Bennett $(2004,381)$ terms a 'system of complementary interests held simultaneously' (principle 3).

There is some ambiguity in the literature on the source of individual rights in land. Thus Gluckman $(1965,78)$ asserts that the underlying principle of African land tenure (in common with most 'tribal societies') is that rights to land 'are an incident of political and social status. By virtue of membership in the nation or tribe, every citizen was entitled to claim some land, from the king or chief, or from such political unit as exists in the absence of chiefly authority'. Colson (1963) describes the case of the Valley Tonga of present-day Zambia, where before 1900 people lived in neighbourhoods under the ritual leadership of a sikatonga. Individual cultivators had rights over land they brought into cultivation and 'no authority within the community had the right to allocate land' (ibid., 141). Men and women were 'equally eligible' to receive lineage land (ibid., 142). Colson $(1971,197)$ argues that land rights in pre-colonial Central Africa could not be bought nor ceded 'any more than the citizenship upon which it rested'.

For Biebuyck (1963, 55), writing from an Africa-wide perspective, land allocation was not necessarily undertaken by the representatives of the landholding groups; the primary role of chiefs and elders was often to maintain peace between the land-using units, to defend the integrity of the territory or to ensure its fertility (principle 4). Other ethnographers, in contrast, state that individual land rights derived in the first instance from an allocation by a traditional authority. In Swaziland, for example, according to Kuper $(1969,44)$, 'the land and the people are interlocked, and the political bond between rulers and subjects is based largely on the power that the rulers wield over the soil on which the people live', and 'as representative of the nation, the king allots land to his people' (ibid., 45). ${ }^{7}$

\footnotetext{
Cf. Reader (1966), for a Zululand case. It may be significant that in both the Zulu and Swazi cases state power became highly centralized in the period immediately before colonial subjugation; this may have resulted in a shift in conceptions of the origins of land rights.
} 
Although the anthropological literature often uses the term 'individual rights' in describing how people held residential and arable land, it emphasizes that land was controlled by family units, which were often large 'extended' households of descent groups, and that along with control came a host of social obligations (principle 1). Sansom (1974, 159-62) emphasizes that in most societies in the southern African region family assets were demarcated as 'house property' and 'men's property'. These assets 'were encumbered', the rights of wife and children were maintained against male authority by the possibility of appeals to kin, and rights in grain and other produce gave each wife a 'measure of power and control' (cf. Schapera, 1955, 202, for the Tswana). According to Hunter (1979, 119) a married woman in Pondoland selected her own fields for cultivation, provided she did not encroach on someone else's; they were not allotted to her. Once she turned over the soil, she had an exclusive right to cultivate that field, no matter how long she left it in fallow. There was no limit to the number or size of the fields she could cultivate.

A key feature of pre-colonial African tenure systems was the right of access to and use of shared resources such as grazing, water and a variety of other natural resources (e.g. grass for thatching, trees for building, fences and fuel wood, wild fruits and vegetables, clay and sand). Regulation of resource use in the common interest occurred to a greater or lesser extent, and was particularly evident in relation to grazing. A great deal of variation was evident in relation to the boundaries of the areas within which rights to resource use were shared (principle 5), and thus also in relation to the location of administrative authority with regulatory responsibilities (Sansom 1974).

Many ethnographic studies describe land administration functions, along with other aspects of authority (judicial, military, religious) as practised at different levels of authority, nested or layered within one another (principle 4). Schapera $(1955,89)$, for example, describes how in Tswana tribes the regulation of common property resources often took place at higher levels of authority, but the acquisition of rights to residential and arable land was highly decentralized. In the first instance, a man would ask his father for a space to build his dwellings, and for fields to plough; if not available, he might try to acquire some land from a relative or friend; if that did not succeed he would apply to the headman for some ward land held in reserve; and only if none was available would the headman take the applicant to the chief for an allocation (ibid., 204).

Sansom (1974) reviews a large number of cases (Tswana, Sotho, Pedi, Zulu, Mpondo, Lovedu, Venda) and suggests that 'a similar apparatus for the delegation of authority to administer rights in land is found in all Southern Bantu tribes' $(1974,145)$. He follows Gluckman (1965) in describing the nested nature of land administration in terms of a series of estates. The anthropological literature on political authority describes both the revered status of leaders and a number of checks on their power, notably through the threat of desertion by followers (Mamdani 1996, 42-6; for the Tswana case see Schapera 1955, 62-3; for the amaPondo see Hunter 1979, 393). The difficulties of exerting centralized political control over commoners are stressed by Kuper (1997, 74-5): 
In pre-conquest south-east Africa the political units ... were typically made up of diverse populations, yoked together by a leader. There were no tribal, homogeneous chiefdoms, and no stable political communities until some were deliberately established by colonial rulers. At any one time, the allegiance and autonomy of various major chiefs was open to question ... The social and political boundaries of the chief's domain were always contentious. There was a constant leakage of commoner households from central control ... amongst the Xhosa the most effective check on chiefly authority was 'gradual emigration'.

\section{The Colonial Period}

The imposition of colonial rule impacted upon how land was held and used. According to Biebuyck $(1963,56)$ the early colonial period was characterized by increasing scarcity of land due to increased population, agricultural development, the development of new markets and a heightened demand for good quality land. Governments passed laws on land, disputes came before the courts and large-scale resettlement of people took place. There was a range of responses to these new circumstances. New ideologies of inheritance and economic co-operation came into being. Sales of land became widespread in some areas, but elsewhere were spurned; in some places rights became highly individualized, in others they remained under the control of groups or political authorities. A general tendency in areas where land was vested in 'villages' was for inheritance rights to fields to be exercised more strongly by individuals and families than before, and where it was held by kinship groupings, the size and genealogical depth of these groups tended to shrink (ibid., 59). Nevertheless, in general land relations remained socially embedded (principle 1). Biebuyck $(1963,60)$ notes that:

in many situations the growth of a feeling of insecurity and of hostility towards outsiders, as the outcome of increased land scarcity and greater demand for land, have resulted in stressing the concepts of inalienability, of group ownership and of ritual sanction in land tenure.

In South Africa, the government of the Cape Colony attempted to provide individual titles in some of the 'native reserves'. The Native Locations and Commonage Act of 1879 allowed the Governor to divide land in the Ciskei into individual 'quitrent' titles with areas reserved as communal grazing but in a diluted and discriminatory form - no conversions to freehold were allowed, and a title-holder could not alienate his land without permission. The response was disappointing - there was a widespread failure to take up titles, in part because of reluctance to pay the costs of survey and titling, in part, according to the Surveyor-General, a 'preference for tribal or common tenure' (Delius et al. 1997, 10). Another attempt, the Glen Grey Act of 1894, was portrayed as 'modernizing' the conditions of African rural existence, but was designed principally to facilitate the supply of migrant workers to the mining industry. Married men were entitled to only one arable plot and security of tenure was not

(C) 2007 The Author.

Journal compilation @ 2007 Blackwell Publishing Ltd, Henry Bernstein and Terence J. Byres. Journal of Agrarian Change, Vol. 7 No. 3, July 2007, pp. 281-315. 
very strong. As with quitrent, the new system experienced problems: boundaries of cultivated lands were not observed, the distinction between arable and commonage land became blurred, and inherited titles were often not registered.

In Natal, by contrast, individualization of land rights was not pursued. Pursuing a policy of indirect rule, the British provided a central role for chiefs in local administration. Customary law was recognized where it was deemed to be 'not repugnant to the general principles of humanity' (cited in Delius et al. 1997, 19). Many of the despotic powers enjoyed by Zulu chiefs under Shaka were enshrined in law.

In the Transvaal, a relatively weak Boer state and determined resistance by Africans meant that for much of the nineteenth century 'competing systems and conceptions of land rights co-existed in varying degrees of tension and conflict' (Delius et al. 1997, 24). There were debates about establishing reserves for African settlement, but none were designated until after 1881. Before then, to secure their independent land rights many Africans had no choice but to purchase farms. Since only white burghers could buy land, many communities requested missionaries to purchase farms on their behalf, using money from cattle sales or migrant wages. After 1881 Africans were allowed to acquire land, as long as it was registered in the name of the Superintendent of Natives. Internally the tenure systems continued to operate as versions of 'communal', 'customary' or 'traditional' tenure - although many land purchasing groups were socially heterogeneous and not necessarily 'tribal' in character (Small and Winkler 1992).

According to Sansom (1974, 168-9) the general trend in Southern Africa was towards 'adaptation' of customary tenure to meet the new conditions of land shortage resulting from both population increase and the restrictions of Africans to the reserves. He cites Gluckman's (1961) view that the basic principle that every male member of the tribe has a right to land to support his family was generally upheld by chiefs (principle 2), who were then forced by scarcity progressively to commandeer and re-allocate first unused land, then fallowed land, and then to restrict each family to a defined area. Sansom also cites evidence of bribery of chiefs in relation to land (ibid., 169).

Chanock $(1991,64)$ questions the accuracy of models of customary land tenure developed in the early colonial period, and suggests that:

The development of the concept of a leading customary role for the chiefs with regard to ownership and allocation of land was fundamental to the evolution of the paradigm of customary tenure ... the chiefs were seen as the holders of land with rights of administration and allocation. Rights in land were seen as flowing downward. Whatever they were, they were derived from the political authority, rather than residing in the peasantry.

This essentially feudal model suited colonial powers seeking to acquire land for settlers and urban settlements and became part of the apparatus of indirect rule. As a consequence, both individual ownership and sales of 


\section{Ben Cousins}

land were anathema, because these would 'tend to disrupt the native polity' 8 A model based on chiefs' control over land helped to underpin a system of local political control (ibid., 69).

In addition, there was 'spirited opposition to individuation' from within African society itself (ibid., 66). This was partly because the ambitions of settlers and corporations to increase their land holdings and to limit those of Africans aroused the resentment and anxiety of peoples already displaced and fearing further loss of their land. Communalism was 'a way of certifying African control of occupation, use, and allocation of land, rather than a description of rights exercised. Individualism was a code word for sale to Europeans' (ibid., 66).

Chanock recommends stepping back from attempts at systematization, and from 'ideologies of traditional communalism' (ibid., 70). Instead, questions should be asked about specific conflicts of interest over land during the colonial period: just who was pressing for a greater individualization of rights? What sort of rights did they have in mind? Who was resisting this pressure, and why?

A cultivator might say 'mine' when title was challenged, or if it was advantageous to sell or mortgage, may think in terms of 'ours' - in terms of nuclear family when asserting a right of inheritance against a larger group of kin, or 'ours' in terms of a lineage - if the claimant was outside the lineage (as a spouse might be). (ibid., 72-3).

A detailed account of the changing character of 'communal tenure' over time is found in Beinart's (1982) study of Pondoland. In the mid-nineteenth century relationships between chiefs and their people were structured mainly by the social relations governing the circulation of cattle, in the form of loans and bridewealth payments, through which followings were built and homesteads extended. According to Beinart $(1982,18)$ :

Chiefs certainly did not exercise their power primarily by controlling access to specific pieces of land. Once a group had been accepted by the chief and had an area of settlement pointed out, the distribution of land for cultivation was largely left to individual homestead heads. . . . Chiefs did, however, exercise more direct control over communal resources such as the major forests.

Pondoland was annexed by the Cape in 1894, the area was divided into districts under the control of colonial magistrates and hut taxes were introduced. Districts were divided into locations under government appointed headmen. Most chiefs became headmen, but their geographical jurisdiction was limited to one location even if it had previously been much larger; commoners were also elevated to chieftaincies. These appointments and the associated delimitation of boundaries generated major disputes, and became part of a struggle between the colonial state and the paramount chief for the support of headmen. This, together with their intermediate position between the state and the people, allowed headmen

8 Meek (1946) cited in Chanock (1991, 64).

(C) 2007 The Author.

Journal compilation (c) 2007 Blackwell Publishing Ltd, Henry Bernstein and Terence J. Byres. Journal of Agrarian Change, Vol. 7 No. 3, July 2007, pp. 281-315. 
to build local power base for themselves, and undermined the system of paying tribute or 'customary dues' to chiefs, which declined. Wage labour became vitally important, and advances of cattle by traders against future migrant income altered the balance of power within large, composite homesteads. Younger migrant men gained more independent access to wives and could begin to establish their own homesteads. Homestead heads began to play a less central role in the allocation of land, which was in any case seen by the colonial state as a function of headmen (ibid., 97).

In the early decades of the twentieth century, chiefs and headmen resisted any attempts to dispossess Mpondo of their land or to radically alter the system of communal tenure. A minority of wealthier cultivators who wanted to grow cash crops and extend their arable lands may have found communal tenure a constraint, but the majority of the rural population supported communal tenure because it was 'their ultimate guarantee of access to both arable plots and grazing' (ibid., 126). Furthermore, the allocation of land through chiefs and headmen enabled ordinary people to 'exercise some control over land' through influencing local political processes, and communal tenure 'was symbolized by the powers of the chieftaincy'. For Beinart this apparent convergence should not obscure the fact that significant changes in the tenure system had occurred and that 'there were different shadings of interest at work' (ibid., 126), explaining persistent tensions between chiefs, headmen, the administration and commoners. This account echoes Chanock's $(1991,70)$ emphasis on interest groups and power relations as the key to understanding both continuities and changes in land tenure through the colonial transition.

These interests were deeply gendered, as Beinart's account makes clear. Walker emphasizes shifts in the character of women's land rights, in the context of pressures towards individualized interpretations of custom:

the interpretation of 'customary' law by colonial administrators and magistrates served to strengthen, not weaken, patriarchal controls over women and to freeze a level of subordination to male kin (father, husband, brother-in-law, son) that was unknown in precolonial societies ... this project involved not simply the imposition of eurocentric views and prejudices on the part of colonisers, but also the collusion of male patriarchs within African society, who were anxious to shore up their diminishing control over female reproductive and productive power. (Walker 2002, 11)

In sum, indigenous social formations in Southern African societies were deeply affected by the transition to colonial rule and the incorporation of local agrarian economies into wider political and economic relations. These resulted in a number of (sometimes contradictory) changes in and adaptations of pre-colonial tenure regimes: (a) a greater stress on individual and family rights and decisionmaking in relation to land; (b) a defensive stress on the group-based nature of land rights; (c) redefinitions of women's land rights as 'secondary' and subordinate to those of husbands and men; (d) chiefs and headmen becoming the symbol of resistance to colonial rule and loss of land; (e) chiefs and headmen being used by 
the state as instruments of indirect rule and as a result acquiring greater powers over land than they had previously enjoyed; (f) the erosion of mechanisms that constrained the power of traditional leaders and kept them responsive to rights holders, these being replaced by a requirement for 'upward accountability' to the state, creating opportunities for abuse of power and corruption.

Despite the clear evidence of change, continuities are also observable. The principles identified above are much in evidence in descriptions of a variety of specific land tenure regimes in the colonial period, with individual and family rights to land remaining defined and limited by social relations and collective identities to varying degrees, even where they were asserted more strongly than before in response to changing conditions. Land rights continued to be derived in the first instance from accepted membership of a group, with outsiders able to join the group through a variety of mechanisms. Production systems continued to include shared grazing areas and household use of other common property resources. In relation to principle 4 (the clear distinction between access and control) it is clear that policies of indirect rule, and the 'decentralized despotism' they gave rise to (Mamdani 1996) led to tighter control over land allocation by chiefs and headmen than had been the case in many tenure systems in the precolonial era - nevertheless, many decisions over land continued to be made at the lower levels of the hierarchy of traditional authority.

\section{The Era of Segregation and Apartheid}

The 1913 Land Act was intended to lay the basis for a 'segregationist social order' in the newly established Union of South Africa. It did not create the reserve system so much as entrench the existing locations and overall distribution of land. The Act was a holding measure while the Beaumont Commission developed recommendations for a permanent land dispensation. The scheduled 'native areas' covered 7 per cent of the land area of the country, but in practice Africans occupied a much larger area. There were long delays in the making of policy, and the impasse created a need to allow African land purchases outside the scheduled areas, which was possible if the Governor General gave his approval. Land so acquired was held in trust by the Minister of Native Affairs, and had to be effected on a 'tribal' basis rather than as a purchase as a 'community' or a partnership. Some groups, however, managed to purchase land as companies (Delius et al. 1997).

The 1936 Land and Trust Act added another 6 per cent of the country to the area in which Africans would be allowed land rights. A body called the South African Native Trust $^{9}$ was established, in which all crown land set aside for 'native occupation' would vest. The Act also allowed regulations to 'prescribe the conditions on which natives may hire, purchase or occupy land held by the Trust', and to control soil erosion. Regulations were passed that drastically

9 Later renamed the South African Development Trust (SADT).

(C) 2007 The Author.

Journal compilation (c) 2007 Blackwell Publishing Ltd, Henry Bernstein and Terence J. Byres. Journal of Agrarian Change, Vol. 7 No. 3, July 2007, pp. 281-315. 
reduced tenure security. Land holders' rights to transfer or bequeath land were limited, the size of allotments was set and women's land rights were severely circumscribed. As Delius et al. $(1997,38)$ comment, 'access to land depended upon the whims of white officials and strict observation of a host of regulations', and there was 'a reduction in the scope for flexibility and diversity in land holdings which had characterized "customary" systems'. Resentment of this pattern of intensified state intervention in land tenure helped provoke major rural revolts (as in Sekhukhuneland and Pondoland) from the 1940s to the early 1960s (Chaskalson 1987). Trust land was also used by the state to accommodate the victims of forced removals or farm evictions from the 1950s onwards.

Large numbers of farms purchased and long-settled by Africans became known as 'black spots'. Located mostly in the Transvaal and Natal, they were targeted for forced removals when apartheid policies were implemented after 1950. Often operating systems of communal tenure within their boundaries, these areas also accommodated large numbers of evictees from farms, usually as tenants of the land owners in the (black) areas they were moved to, partly due to the continuing strength of the African land ethic. The high population densities that resulted often led to severe strains on the tenure system.

A drive towards uniform approaches and increased levels of state interference was evident in the Native Administration Act of 1927 (Delius et al. 1997). Africans were to be governed in a distinct domain legitimated by 'custom' and chiefly rule, but under strict control from above. The Governor General, as 'supreme chief of all natives in the provinces of Natal, Transvaal and the Orange Free State' could recognize or appoint anyone as a chief or headman and define the boundaries of any tribe or location.

The Bantu Authorities Act of 1951, along with betterment planning and authoritarian regulation of land rights under Trust tenure, was a key factor in the rural rebellions of the 1950s (Mbeki 1964). It involved the establishment of tribal authorities, a version of 'traditional rule' that was highly authoritarian, 'stripped of many of the elements of popular representation and accountability which had existed within pre-colonial political systems and which had to some extent survived within ... the reserves' (Delius et al. 1997, 39). Many chiefs used their new-found powers and reduced accountability to allocate better quality land to themselves and their supporters, and to demand higher payments for allocations (Mbeki 1964; Mamdani 1996; Ntsebeza 2003).

Proclamation R.188 of 1969, issued under the powers vested in the State President (formerly the Governor General) under the Native Administration Act and the 1936 Land Act, was intended to regulate further the operation of land tenure in black areas. Two forms of tenure were recognized - quitrent for surveyed land and 'Permission to Occupy' (PTO) certificates for unsurveyed land. Severe limitations on the content of the rights of holders were laid down, e.g. one man-one lot; restrictions on plot size; a rigid system of male primogeniture to govern inheritance; and non-recognition of female land rights. Officials were given extensive powers to appropriate land and to cancel quitrent titles and PTOs. Chiefs and headmen undertook the task of allocation, agricultural officers 


\section{Ben Cousins}

surveyed the boundaries of sites and fields, and magistrates issued the PTOs. Registers of permit holders were kept at the magistrate's offices.

In the Bantustan era (1948-1990) large areas of land occupied by blacks (including, in the Transvaal in particular, a large number of purchased farms) were transferred to the 'self-governing territories' and many communities were placed under the jurisdiction of government-recognized chiefs and Tribal Authorities. The governments of the Bantustans passed a host of laws to further regulate land tenure.

In the colonial and apartheid eras the retention of 'communal' land tenure was intended to underpin cheap labour policies and cost-effective control of rural populations from above. But the system also widened access to relatively independent, land-based livelihoods and helped rural communities to resist exploitation and state control, and was often actively defended by them (Delius et al. 1997; Beinart 1982). The effect was to provide elements of both continuity and change in land tenure systems, to varying degrees in different areas, depending on the outcomes of local political struggles and how, and how much, state policies were implemented.

\section{The Contemporary Period}

Most contemporary South African case studies of 'communal tenure' echo earlier ethnographic descriptions in characterizing land tenure in the former reserves as being simultaneously 'communal' and 'individual' in nature (principle 3 ). ${ }^{10}$ This literature also contains contrasting interpretations of the origin of land rights and the meaning of 'land allocation': some authors portray rights as deriving primarily from allocations of plots by an authority structure (Oomen 2005, 157-8, Ntsebeza 1999, 75, 101; Ntsebeza 2003, 219-20), while others see the origin of rights in accepted membership of a 'community', and portray 'allocation' as an essentially administrative procedure to ensure that land is distributed fairly and to avoid boundary disputes (Alcock and Hornby 2004, 13). Fay (2005, 189-90) describes land access in Hobeni in the Eastern Cape as occurring largely through inheritance or sub-division of existing plots, without any need to consult with the headman or sub-headman (principle 4). Small and Winkler $(1992,6)$ describe land allocation amongst the Bafarutse ba Braklaagte as being undertaken by an elder representing the clan on the kgotla (council of elders) within large areas set aside for extended family groups or clans (kgoros).

Rights to residential and arable plots are usually portrayed as being held by households with married men at their head (Alcock and Hornby 2004; Cross and Friedman 1997; Turner 1999). In some contexts single women with children to

\footnotetext{
10 For KwaZulu-Natal, see Alcock and Hornby (2004), Cross (1994), Ferguson and Sithole (2004), Hornby (2000), Liversage (1993), Sithole (2004) and Walker (1997); for Eastern Cape, see de Wet (1995), Fay (2005), Kingwill (1996), Kepe (1999, 2001), McAllister (2001), Ntsebeza (1999) and Turner (1999); for Limpopo, see Claassens (2001); Lahiff (2000), Lahiff and Aphane (2000) and Oomen (2000, 2005); for North West, see Small and Winkler (1992); for Mpumalanga, see Levin and Mkhabela (1997) and Small and Winkler (1992).
} 
support are also allocated land (Fay 2005; Meer 1997; Sithole 2004; Thorp 1997). The principle that families who need land to establish an independent base for their livelihoods must be allocated plots is still widely upheld. The pre-1994 system of issuing Permission to Occupy (PTO) certificates is still in place in some areas and provinces but not in others. Whether or not officials still survey and demarcate plots, as they used to do in the apartheid period, is also highly variable (Macintosh, Xaba and Associates 1998). The lack of clarity over how land should be administered at present can itself gives rise to tensions and disputes over land rights (Lahiff and Aphane 2000; Turner 1999; Macintosh, Xaba and Associates 1998).

The idea that communal land cannot be bought or sold is still strongly articulated by many residents (Alcock and Hornby 2004, 17), but in some areas, such as Pondoland, it is evident that sales do in fact take place (Kepe, personal communication). Sale of buildings or other permanent improvements such as fruit trees is usually seen as acceptable, but allocation of the land itself must then follow a procedure similar to that followed when outsiders apply for land (Turner 1999, 13). However, in some areas chiefs and headmen sell land to outsiders without such procedures being applied (Ntsebeza 1999, 74-5; Oomen 2005, 158, 173).

In Ekuthuleni, a former mission station farm in KwaZulu-Natal, landholders have the right to allocate, lend and bequeath their land, and to sell houses hence, in effect, the land they occupy (Hornby 2000). Relatives who need land (including single mothers, widows and elderly women) are generally allocated plots, and in practice neither allocations nor sales to outsiders currently occur. Vacant land is the responsibility of the local headman or nduna to allocate in consultation with an ibandla (group of neighbours). There is currently a lack of agreement over some aspects of the tenure system (e.g. whether or not loans are permanent, and whether or not payment to the nduna is required), over precisely what a land allocation means, and over how disputes should be resolved. This has led to anxiety over tenure security, deriving from 'unclear adaptations of rules and procedures', themselves an indication of 'processes of change in response to internal and external pressures' (Ziqubu et al. 2001, 6).

In some parts of the country the apartheid-era relocation of large numbers of people, together with attempts to consolidate 'homeland' boundaries and the placement of all rural residents under the jurisdiction of a tribal authority, led to the creation of patchworks of farms occupied by groups of diverse origin and identity. Registered titles are sometimes held by different 'owners', and some farms are subject to competing restitution claims. Two detailed case studies from Limpopo Province illustrate the complexities and the tensions that can result Dikgale (Lahiff and Aphane 2000) and Rakgwadi (Claassens 2001; Small 1997). These illustrate a more general point: simplistic notions of homogenous 'communities', with clearly defined social and territorial boundaries and under the accepted authority of traditional leaders, are inappropriate in many communal areas in South Africa.

Awareness of post-1994 constitutional rights to gender equality has led to recognition in some areas that widows, unmarried women and divorcees with 


\section{Ben Cousins}

children to support are entitled to land in their own right (Alcock and Hornby 2004; Sithole 2004; Turner 1999), but the extent of these new practices appears to be uneven (Claassens and Ngubane 2003). In parts of the Eastern Cape it applies only to residential land (Turner 1999). In Limpopo province it has been reported that women are particularly vulnerable to accusations of witchcraft, which constitutes grounds for loss of land rights (Lahiff and Aphane 2000, 26). Because of these problems, some women in communal areas are in favour of individual title as a way to secure their independent land rights (Claassens 2003).

Contemporary studies reveal that rights of access to common property resources are still important for rural livelihoods in many areas (Shackleton et al. 2000). Rights to land usually include rights to use or collect natural resources from the commons (principle 3). In some cases rights and duties are subject to well-defined community rules and management regimes, enforced by local authorities such as traditional leaders or elected committees (Cousins 1996; McAllister 2001). In others these management regimes have broken down and 'open access' prevails (Turner 1999). The area within which community members may use or collect common property resources usually varies by the resource in question (principles 4 and 5). For example, often grazing is restricted to the boundaries of a village, or of a group of villages under a headman (sometimes called 'wards' or 'administrative areas', or isigodi in Kwazulu-Natal). Primary rights to use resources such as forest patches or woodlots may be held by specific villages, or wards, or may be held by members of the wider 'community' (e.g. the 'tribe'). In most cases these boundaries are flexible and negotiable, rather than being exclusive (Alcock and Hornby 2004). They can also be the focus of conflicts (Cousins 1996; Turner 1999).

Many case studies show that land administration is spatially and institutionally nested (principle 4). Despite attempts by colonial and apartheid regimes to centralize decision-making in the hands of an 'upwardly accountable' traditional leadership, in many areas allocations of residential and arable land to newcomers are still undertaken at the local level and involve prospective neighbours as key decisionmakers, usually under the oversight of either a traditional or an elected leadership (Alcock and Hornby 2004; Fay 2005; Ntsebeza 2003; Turner 1999). The relevant social and administrative unit is variously termed a neighbourhood (e.g. the isithebe in Pondoland), a sub-ward (umhlati in isiZulu speaking areas), a subvillage or a village. In some places traditional leadership is no longer seen as legitimate and elected committees play these roles (Turner 1999).

Fay (2005) describes the situation in Hobeni in the Eastern Cape as one in which land access is governed at the level of the neighbourhood, with variations in tenure practices related to their kinship composition. These neighbourhoods are nested within a number of larger structures, but primary decision-making rests with 'those who inhabit and use the land: neighbourhoods organised under subheadmen' - and is characterized by 'downward accountability and flexibility' (ibid., 199).

Land allocation to an outsider often requires payment by the applicant of a fee of some kind, seen as 'chief's dues' in some places, or an indication of acceptance 
of the authority of traditional structures (khonza in isiZulu speaking areas), or simply as an administrative fee (Alcock and Hornby 2004; Kepe personal communication). However, in many places payments for land rights are made to chiefs or headmen without any oversight by neighbours or the wider community (Ntsebeza 1999; Oomen 2005) who often perceive this as corruption (Claassens 2003).

The contemporary literature contains many examples of underlying commonalities and continuities in land tenure regimes. These studies also show, however, that social and political values, identities and relationships are under stress as a result of ongoing processes of change, giving rise to tension and conflicts over the precise definition of both collective identities and individual rights (Claassens 2001; Hornby 2000; Kepe 1999; Ntsebeza 1999; Oomen 2005). 'Community members' are increasingly of heterogeneous social origin, given high levels of mobility, and acquisition of rights via birth is only one of several routes to such membership. Although not documented much in the available literature, anecdotal evidence suggests that purchase is an increasingly common mechanism for acquiring land rights, either from individual residents or from traditional leaders.

\section{Commonality and Continuity}

The five 'underlying principles' identified here might have a degree of validity as descriptions of key elements of 'communal' tenure regimes, but this is a different matter to explaining why, in some instances, to different degrees, and in different ways, they have persisted over time and are shared across a range of variable conditions and circumstances. Explanation is always more challenging than description, and I do not attempt to address this issue in a systematic manner here, suggesting only some possible lines of enquiry. Commonalities and continuities may arise as a result of a combination of these factors:

(a) similar state policies in different times and places that aimed at preserving 'customary' regimes of land tenure and governance, such as policies to create and maintain labour reserves for migrant labour, or to save costs in maintaining order through systems of 'indirect rule' via chiefs;

(b) the practical advantages of 'communal' tenure to Africans, who across the region were losing or had lost land to settlers and saw this form of tenure as a way to collectively defend their rights to productive resources (cf. Beinart 1982);

(c) the significance of common property resources and rights within production systems based on dryland cropping, animal traction and communal grazing, or on shifting cultivation, as well as the importance of continued access to other natural resources from the commons;

(d) underlying commonalities in 'culture' and 'values', or perhaps what Guyer $(2004,6)$ calls 'plausible conventions and institutions', those 'persistent elements and relationships by which people individually and collectively create economies'. 


\section{WIDER AFRICAN DEBATES}

What does recent writing on land tenure in Africa more broadly have to say on these issues? One key theme is change and conflict, leading to scepticism about 'idealized' models of communal tenure (Chimhowu and Woodhouse 2006, 348). Berry's (1993) influential view that property rights are flexible and involve ongoing social and political processes of negotiation as the key to understanding is being challenged. Pauline Peters (2002, 2004), for example, take issue with dominant images of African land tenure as 'relatively open, negotiable and adaptive customary systems', and stresses instead 'processes of exclusion, deepening social divisions and class formation'. She suggests that 'commodification, structural adjustment, market liberalisation and globalization' tend to 'limit or end negotiation and flexibility for certain social groups or categories' (Peters 2004, 270).

Competition and conflict over land are increasing in Africa, Peters argues, because of the confluence of a number of intersecting processes: the need of many rural families to produce more from their land even though inputs are declining; civil servants and others in employment seeking to produce food and cash crops from family land; the state and environmental groups trying to extend the area under conservation; and the intensification of the exploitation of resources such as minerals, wildlife, water, trees etc. (ibid., 286). These realities require analysts to go beyond formulations of land being 'socially embedded' in order to raise questions about 'the type of social and political relations in which land is situated, particularly with reference to relations of inequality - of class, ethnicity, gender and age' (ibid., 278). Peters sees a key 'socio-cultural dynamic of differentiation' emerging within social units such as the family, lineage, village, "tribe" or ethnically defined group', which can be understood as 'a process of narrowing in the definition of belonging', with 'group boundaries [becoming] more exclusively defined' (ibid., 302).

Other scholars have drawn attention to the increasing prevalence of land being acquired through a variety of market transactions, including purchase, rental and sharecropping (Andre 2003; Daley 2005a, 2005b; Chimhowu and Woodhouse 2006; Lund 2001; Mathieu et al. 2003; Sjaastad 2003; Woodhouse 2003). This brings with it 'an increasing individualization of control of land and in some instances its alienation from any form of customary authority, amounting to effective privatization of land' (Chimhowu and Woodhouse 2006, 352). In most cases, however, market-based access 'remains encumbered by customary tenure', and hence transactions in these 'vernacular' land markets have no form of statutory protection (ibid., 392). Scarcity of land due to population growth is only one driver of this process; others include the growth of markets for agricultural commodities (e.g. horticultural products for urban markets), the impact of new technologies for water management, tree cropping or crop transport, growth in non-farm and wage income, population migration, and urbanization and the emergence of land markets in 'customary' areas around towns and cities (ibid., 353-6). Three main categories of buyers are identified - 'new big men' 
with jobs and influence, migrants without claims to customary rights and those with kinship ties in areas where land is scarce, who purchase or rent from senior male relatives. Key sellers are 'senior men' and especially tribal chiefs (ibid., 359). For Chimhowu and Woodhouse, land policies need to consider the "key question' of how 'regulation and reform of such markets relates to their impact on the poor' (ibid., 366).

Some analysts describe the emergence of informal institutional innovations in the recording of signed documents to legitimize increasingly widespread transactions in land, in an attempt to reduce the ambiguity and uncertainty associated with the rights so acquired (Andre 2003; Lavigne Delville 2003; Mathieu et al. 2003). They can involve local officials (who witness these transactions in the name of the government department they represent, but according to 'unofficial rules') as well as private individuals with local legitimacy (Lavigne Delville 2003, 102). These records are often not sufficient, however, to prevent their being contested by others with prior claims based on kinship or custom (Chimhowu and Woodhouse 2005, 400; Mathieu et al. 2003, 123), and 'idioms of tradition' together with 'the perseverance of local politics and the logic of inclusion' preclude easy assumptions as to the exclusionary outcomes of such processes (Benjaminsen and Lund 2003, 9).

The picture that emerges from these studies is not one of steady evolutionary change towards individualized forms of property and the disappearance of 'customary' identities and claims to land. Mathieu et al. (2003, 126-7) suggest that where land becomes scarce and has increasing economic value, 'there is a social demand for more individualized, precise and formalized land ownership rights', but that 'this change is not so simple, nor is it linear or automatic'. The process is 'totally embedded in social relationships' and hence 'contradictory, complex and ambiguous', since past meanings of land 'retain their significance in the local social reality'. Chimhowu and Woodhouse $(2005,401)$ acknowledge that "the transition from the "gifts" expected as tokens of acknowledgement of customary authority and of anticipated reciprocity, to payments more closely related to exchange values of the land, is not always easy to define'. Lund (2001, 157-9) points out that formalization of individual and private titles, as in Kenya, has not necessarily produced greater certainty and security of land rights because of a lack of social legitimacy, and that processes of 'informal formalisation' probably depend on a degree of uncertainty remaining as to the status of such transactions at the 'margins of the law as well as of customs'.

More generally, processes of change often generate resistance, contestation and the re-assertion of 'customary' claims to land. As Peters $(2004,302)$ suggests (citing Woodhouse et al. 2000,2) they are inevitably 'uneven and contradictory' in character. 'Moreover, boundaries, physical and legal, do not automatically ensure exclusion where (some of) the excluded reject the legitimacy of the exclusion' (Peters 2004, 303). Alongside change is continuity in the nature of land rights, argued for and actively reproduced because of its advantages for many within the rural population, including, in some contexts, women (Odgaaard 2003, 83). Flexibility and negotiability, which in many places have given way to differentiation 


\section{Ben Cousins}

and exclusion, 'remain an important asset to small-scale producers across the continent' (Peters 2004, 305-6).

This brief excursion into the wider literature suggests that contemporary processes of social, economic and political change can produce fundamental shifts in the nature of land rights and associated systems of authority, so that the distinctive features discussed above may no longer be present as 'underlying principles'. However, there is also evidence that the social and political embeddedness of land relations remains key to understanding how land tenure systems work in practice, and that in many cases land rights are still shared rather than exclusive, are based on accepted group membership, involve access to the commons, and are nested or layered in character - in short, that these principles have not been completely eclipsed in contemporary Africa, and assist in understanding the nature of current processes of change.

\section{ALTERNATIVE APPROACHES TO TENURE REFORM}

What are the implications of this analysis for policy? In the South African context, debates around the Communal Land Rights Act demonstrate how problematic attempts to recognize 'customary' land rights can be. In a larger context where private property dominates and security of tenure is equated with exclusive ownership, but chiefs continue to be a significant political interest group, transferring private ownership to 'traditional communities' ruled by traditional councils, and without effective mechanisms for downward accountability, threatens rather than secures land rights. One reason, as Aninka Claassens and I have argued (Cousins and Claassens 2004), is that this approach entrenches a version of 'custom' that emerged during the colonial era, and continues to lead to abuses of power.

In my view, the underlying principles identified above have proved remarkably resilient in the South African context, informing context-specific practices that evolve over time. Is there a way, then, to secure these distinctive forms of land rights without replicating problematic versions of 'custom', and in a manner that promotes democratic decision-making? Can policy both secure rights on the ground, and also allow rights-holders to adapt or alter their tenure system through deliberate choices over time in response to changing circumstances? Relevant here are the tenure reform principles set out in the South African White Paper on Land Policy (DLA 1997). These require that the law be brought in line with de facto realities, but that these realities also be transformed to bring them in line with constitutional principles of democracy and equality, and thus to include freedom of choice in relation to both land rights and the institutions that will administer those rights.

The way beyond the 'customs versus rights' polarity, I suggest, is to vest land rights in individuals rather than in groups or institutions, and to make socially legitimate existing occupation and use, or de facto 'rights', the primary basis for legal recognition. These claims may or may not be justified by reference to 'custom'. Rights holders would be entitled to define collectively the precise 
content of their rights, and choose, by majority vote, the representatives who will administer their land rights (e.g. by keeping records, enforcing rules and mediating disputes). Accountability of these representatives would be downwards to group members, not upwards to the state. Gender equality would be a requirement before legal recognition of rights could occur.

A key question is the nature of those individual rights. I am not suggesting a form of individual titling, which has been so problematic in Africa, but rather a form of statutory right that is legally secure but also qualified by the rights of others within a range of nested social units, from the family through user groups to villages and other larger 'communities' with shared rights to a range of common property resources. Women's rights within the family as well as other units need to be explicitly recognized.

Another central issue is the boundaries of the relevant social units within which land rights are held, and should therefore be the key decision-making units. Again, existing practice that is socially legitimate could provide the basis for decisions by groups of rights-holders as to their social and territorial boundaries, and allow legal recognition of grounded institutional realities, within a framework that requires the democratization of decision-making. A key requirement, however, would be recognition of the relatively flexible nature of those boundaries, depending on the resources and decisions in question, and given the nested or layered character of rights to shared resources. There would thus need to be acknowledgment of the multiple 'communities' within which land rights are held.

This approach does not require attempts at codification of what are likely to be dynamic and changing practices, but does allow the key features of property regimes that are distinct from 'Western-legal' regimes to be secured in law. Moore's (1998) and Berry's (1990) suggestions that policy must aim to strengthen institutional spaces for the mediation of competing claims to land are critically important, but so are the views of Lavigne Delville (1999), Peters (2004) and Woodhouse (2003), who emphasize that unequal power relations within local institutional contexts have to be addressed. What is 'socially legitimate' is always subject to contestation. This means that the political embeddedness of land rights must be explicitly acknowledged. Democratizing land administration will require providing support to rights-holders within local institutional processes, and a degree of central government oversight (Woodhouse 2003). In addition to clarifying the nature of the rights at stake, this approach could provide 'a framework for their further evolution' (Sawadogo and Stamm 2000, cited by Daley and Hobley 2005, 35).

\section{CONCLUSION}

Land tenure reform remains a key policy issue in Africa, given the large proportion of the population that relies on land and natural resources for their livelihoods. It is not enough to recognize the socially and politically embedded character of land rights, or the unequal outcomes of contemporary forms of 'enclosure'. 
Privatization and complete individualization of land are uneven and contested, and in many places the nature and content of land rights remain quite distinct from 'Western-legal' forms of property. In these situations, individual titling is not a feasible solution. If one adopts a 'rights without illusions' perspective (Hunt 1991), legal recognition of these distinctive forms of land rights can form part of a broader strategy to secure rights through political struggle, and must involve external support for rights holders within local institutional and political processes.

The alternative to individual titling is not a simple ratification of current systems of 'customary' land rights, which often privilege both traditional and non-traditional 'big men' (and men in general) - but vesting rights in individuals who share rights with others within a variety of nested social units, the territorial boundaries of which vary with the resource or decision at issue, and are thus flexible. The alternative approach also requires that decisions concerning these shared and relative rights are subject to the democratic principle of downward accountability to a majority of rights-holders. In turn this implies a key role for the central state in overseeing local governance. This takes us beyond the 'custom vs rights' polarity, in a manner that accords with the perspectives of many of those affected, like the rural groupings challenging the constitutionality of South Africa's Communal Land Rights Act.

\section{REFERENCES}

Adams, Martin, Ben Cousins and Siyabulela Manona, 2000. 'Land Tenure and Economic Development in Rural South Africa: Constraints and Opportunities'. In At the Crossroads. Land and Agrarian Reform in South Africa into the 21st Century, ed. Ben Cousins, 111-28. Cape Town: Programme for Land and Agrarian Studies, University of the Western Cape and National Land Committee.

Alcock, Rauri and Donna Hornby, 2004. 'Traditional Land Matters. A Look into Land Administration in Tribal Areas in KwaZulu-Natal'. Pietermaritzburg: Legal Entity Assessment Project.

Andre, Catherine, 2003. 'Custom, Contract and Cadastres in North-West Rwanda'. In Securing Land Rights in Africa, eds Tor A. Benjaminsen and Christian Lund, 153-72. London: Frank Cass.

Beinart, William, 1982. The Political Economy of Pondoland, 1860-1930. Johannesburg: Ravan Press.

Beinart, William and Colin Bundy, 1987. Hidden Struggles in Rural South Africa. Politics and Popular Movements in the Transkei and Eastern Cape, 1890-1930. Johannesburg: Ravan Press.

Benjaminsen, Tor A. and Christian Lund, eds, 2001. Politics, Property and Production in the West African Sahel. Uppsala: Nordiska Afrikainstitet.

Benjaminsen, Tor A. and Christian Lund, eds, 2003. Securing Land Rights in Africa. London: Frank Cass.

Bennett, T.W. 2004. Customary Law in South Africa. Cape Town: Juta.

Berry, Sara, 1990. 'Land Tenure and Agricultural Performance in Africa: Report on a Conference'. Paper on Conference on Rural Land Tenure, Credit, Agricultural Investment, and Farm Productivity, 4-8 June 1990. Nairobi. 
Berry, Sara, 1993. No Condition is Permanent. The Social Dynamics of Agrarian Change in sub-Saharan Africa. Madison, WI: University of Wisconsin Press.

Biebuyck, Daniel, 1963. 'Introduction'. In African Agrarian Systems, ed. Daniel Biebuyck, 1-64. London: Oxford University Press.

Bohannon, Paul, 1963. “"Land”, "Tenure”, and "Land Tenure”, '. In African Agrarian Systems, ed. Daniel Biebuyck, 101-15. London: Oxford University Press.

Chanock, Martin, 1991. 'Paradigms, Policies and Property: A Review of the Customary Law of Land Tenure'. In Law in Colonial Africa, eds Kristin Mann and Richard Roberts, 61-84. Portsmouth, NH: Heinemann Educational Books.

Chaskalson, M., 1987. 'Rural Resistance in the 1940s and 1950s'. Africa Perspectives, New Series, 5 and 6: 47-59.

Chimhowu, Admos and Phil Woodhouse, 2006. 'Customary vs Private Property Rights? Dynamics and Trajectories of Vernacular Land Markets in Sub-Saharan in Africa'. Journal of Agrarian Change, 6 (3): 346-71.

Claassens, Aninka, 2000. 'South African Proposals for Tenure Reform: the Draft Land Rights Bill'. In Evolving Land Rights, Policy and Tenure in Africa, eds C. Toulmin and J. Quan, 247-66. London: International Institute for Environment and Development and Natural Resources Institute.

Claassens, Aninka, 2001. 'It Is Not Easy to Challenge a Chief': Lessons from Rakgwadi. Research Report No. 9. Cape Town: Programme for Land and Agrarian Studies, University of the Western Cape.

Claassens, Aninka, 2003. Community Views on the Communal Land Rights Bill. Research Report No. 15. Cape Town: Programme for Land and Agrarian Studies, University of the Western Cape.

Claassens, Aninka, 2005. 'The Communal Land Rights Act and Women: Does the Act Remedy or Entrench Discrimination and the Distortion of the Customary?'. Occasional Paper 28. Cape Town: Programme for Land and Agrarian Studies, University of the Western Cape.

Claassens, Aninka and Sizani Ngubane, 2003. 'Rural Women, Land Rights and the Communal Land Rights Bill'. Unpublished paper presented to conference on 'Women and the Law', Cape Town, Women's Legal Centre.

Colson, Elizabeth, 1963. 'Land Rights and Land Use Among the Valley Tonga of the Rhodesian Federation: the Background to the Kariba Resettlement Programme'. In African Agrarian Systems, ed. Daniel Biebuyck, 137-56. London: Oxford University Press.

Colson, Elizabeth, 1971. 'The Impact of the Colonial Period on the Definition of Land Rights'. In The Impact of Colonialism, ed. Victor Turner, 193-215. Cambridge: Cambridge University Press.

Comaroff, Jean and John Comaroff, 2006. 'Reflections on Liberalism, Policulturalism and ID-ology: Citizenship and Difference in South Africa'. In The Limits of Liberation after Apartheid: Citizenship, Governance and Culture, ed. Steven L. Robins, 33-56. Oxford: James Currey.

Cousins, Ben, 1996. 'Livestock Production and Common Property Struggles in South Africa's Agrarian Reform'. Journal of Peasant Studies, 23 (2 and 3): 166-208.

Cousins, Ben, 2005. 'Tenure Reform in South Africa: Titling versus Social Embeddedness'. Forum for Development Studies, 2: 415-42.

Cousins, Ben and Aninka Claassens, 2004. 'Communal Land Rights, Democracy and Traditional Leaders in Post-apartheid South Africa'. In Securing Land and Resource Rights in Africa: Pan-African Perspectives, ed. M. Saruchera, 139-54. Cape Town: Programme for Land and Agrarian Studies, University of the Western Cape.

(C) 2007 The Author.

Journal compilation (c) 2007 Blackwell Publishing Ltd, Henry Bernstein and Terence J. Byres. Journal of Agrarian Change, Vol. 7 No. 3, July 2007, pp. 281-315. 


\section{Ben Cousins}

Cross, C., 1992. 'An Alternate Legality: the Property Rights Question in Relation to South Africa Land Reform'. South African Journal of Human Rights, 8 (3): 305-33.

Cross, Catherine, 1994. 'Shack Tenure in Durban'. In Here to Stay. Informal Settlements in KwaZulu-Natal, eds Doug Hindson and Jeff McCarthy, 170-90. Durban: Indicator Press.

Cross, Catherine and Michelle Friedman, 1997. 'Women and Tenure: Marginality and the Left-hand Power'. In Women, Land and Authority: Perspectives from South Africa, ed. Shamin Meer, 17-34. Cape Town: David Philip.

Daley, Elizabeth, 2005a. 'Land and Social Change in a Tanzanian Village 1: Kinyanambo, 1920s-1990'. Journal of Agrarian Change, 5 (3): 363-404.

Daley, Elizabeth, 2005b. 'Land and Social Change in a Tanzanian Village 2: Kinyanambo in the 1990s'. Journal of Agrarian Change, 5 (4): 526-72.

Daley, Elizabeth and Mary Hobley, 2005. 'Land: Changing Contexts, Changing Relationships, Changing Rights'. Paper commissioned by Department for International Development.

de Wet, Chris, 1995. Moving Together Drifting Apart. Betterment Planning and Villagisation in a South African Homeland. Johannesburg: Witwatersrand University Press.

Delius, Peter (with Rosalie Kingwill and Matthew Chaskalson), 1997. 'A Historical Investigation of Underlying Rights to Land Registered as State Owned'. Report commissioned by the Tenure Reform Core Group. Pretoria: Department of Land Affairs.

DLA, 1997. White Paper on South African Land Policy. Pretoria: Department of Land Affairs.

Fay, Derick, 2005. 'Kinship and Access to Land in the Eastern Cape: Implications for Land Reform'. Social Dynamics, 31 (1): 182-207.

Ferguson, Cathy and Mpilo Sithole, 2004. 'Intersection of Schemes and Customary Land Use Issues'. Paper presented to workshop on 'Aligning Development Planning with Communal Tenure Arrangements - in the context of changing legislation', Midnet and Legal Entity Assessment Project, Pietermaritzburg.

Gluckman, Max, 1965. The Ideas in Barotse Jurisprudence. Manchester: Manchester University Press.

Govender, Pregs, 2004. 'Parliament Gives Rural Women a Raw Deal'. Sunday Times, 15 February 2004.

Guyer, Jane, 2004. Marginal Gains. Monetary Transactions in Atlantic Africa. Chicago, IL: University of Chicago Press.

Hornby, Donna, 2000. 'Tenure Rights and Practices on a State-owned Farm: The Community of Ekuthuleni'. In At the Crossroads. Land and Agrarian Reform in South Africa into the 21st Century, ed. Ben Cousins, 311-17. Cape Town: Programme for Land and Agrarian Studies, University of the Western Cape and National Land Committee.

Hunt, A., 1991. Explorations in Law and Society. Towards a Constitutive Theory of Law. New York: Routledge.

Hunter, Monica, 1979. Reaction to Conquest. Cape Town: David Philip.

Kepe, Thembela, 1999. "The Problem of Defining "Community": Challenges for the Land Reform Programme in Rural South Africa'. Development Southern Africa, 16 (3): 415-33.

Kepe, Thembela, 2001. Waking Up From the Dream: the Wild Coast SDI and the Pitfalls of 'Fast Track' Development. Research Report No. 8, Cape Town: Programme for Land and Agrarian Studies, School of Government, University of the Western Cape.

Kingwill, Rosalie, 1996. 'Quitrent Tenure'. Material prepared for a training course on South African Land Tenure and Policy, Programme for Land and Agrarian Studies,

(C) 2007 The Author.

Journal compilation (C) 2007 Blackwell Publishing Ltd, Henry Bernstein and Terence J. Byres. Journal of Agrarian Change, Vol. 7 No. 3, July 2007, pp. 281-315. 
School of Government, University of the Western Cape and Land Tenure Center, University of Wisconsin-Madison.

Kuper, Adam, 1997. 'The Academic Frontier. History and Social Anthropology in South Africa'. In Culture and the Commonplace. Anthropological Essays in Honour of David HammondTooke, ed. Patrick McAllister, 69-84. Johannesburg: Witwatersrand University Press. Lahiff, Edward, 2000. 'Land Tenure in South Africa's Communal Areas: A Case Study of the Arabie-Olifants Scheme'. African Studies, 59 (1): 45-69.

Lahiff, Edward and James Aphane, 2000. 'Communal Land Tenure: A Case Study of Dikgale Tribal Area, Northern Province'. Pietersburg (Polokwane): Nkuzi Development Association.

Lavigne Delville, Phillipe, 1999. 'Harmonising Formal Law and Customary Land Rights in French-speaking West Africa'. IIED Issue Paper No. 86, June 1999. London: International Institute for Environment and Development.

Lavigne Delville, Phillipe, 2003. 'When Farmers Use "Pieces of Paper" to Record Their Land Transactions in Francophone Rural Africa: Insights into the Dynamics of Institutional Innovation'. In Securing Land Rights in Africa, eds Tor A. Benjaminsen and Christian Lund, 89-108. London: Frank Cass.

Lentz, Carola, 2006. 'Decentralization, the State and Conflicts over Local Boundaries in Northern Ghana'. Development and Change, 57 (4): 901-19.

Levin, Richard and Sam Mkhabela, 1997. 'The Chieftaincy, Land Allocation and Democracy'. In 'No More Tears'. Struggles for Land in Mpumalanga, South Africa, eds Richard Levin and Daniel Weiner, 153-173. Trenton: Africa World Press.

Liversage, Harry, 1993. 'Amahlubi. A Case Study', Land and Agriculture Policy Centre Research Paper 51, for the World Bank Rural Restructuring Programme for South Africa. Johannesburg: Land and Agriculture Policy Centre.

Lund, Christian, 2001. 'Questioning Some Assumptions About Land Tenure'. In Politics, Property and Production in the West African Sahel, eds Tor A. Benjaminsen and Christian Lund, 144-62. Uppsala: Nordiska Afrikainstitet.

Lund, Christian, 2002. 'Negotiating Property Institutions: the Symbiosis of Property and Authority in Africa'. In Negotiating Property in Africa, eds K. Juul and C. Lund, 11-43. Portsmouth, NH: Heinemann.

McAllister, Patrick, 2001. Building the Homestead: Agriculture, Labour and Beer in South Africa's Transkei. Aldershot: Ashgate, for the African Studies Centre, Leiden.

Macintosh, Xaba and Associates, 1998. Land Administration in the Former Homelands. Report commissioned by the Department of Land Affairs.

Mamdani, Mahmood, 1996. Citizen and Subject: Contemporary Africa and the Legacy of late Colonialism. Princeton, NJ: Princeton University Press.

Mathieu, Paul, Mahamadou Zongo and Lucinan Pare, 2003. 'Monetary Land Transactions in Western Burkino Faso: Commoditisation, Papers and Ambiguities'. In Securing Land Rights in Africa, eds Tor A. Benjaminsen and Christian Lund, 109-28. London: Frank Cass.

Mbeki, Govan, 1964. The Peasant's Revolt. Harmondsworth: Penguin.

Meer, Shamin, ed., 1997. Women, Land and Authority: Perspectives from South Africa. Cape Town: David Philip.

Moore, Sally Falk, 1998. 'Changing African Land Tenure: Reflections on the Incapacities of the State'. European Journal of Development Research, 10 (2): 33-49.

Murray, Christina, 2004. South Africa's Troubled Royalty: Traditional Leaders After Democracy. Canberra: Federation Press in association with the Centre for International and Public Law, Australian National University (Law and Policy Paper No. 3).

() 2007 The Author.

Journal compilation (C) 2007 Blackwell Publishing Ltd, Henry Bernstein and Terence J. Byres. Journal of Agrarian Change, Vol. 7 No. 3, July 2007, pp. 281-315. 


\section{Ben Cousins}

Nhlapo, Thandabantu, 1995. 'African Customary Law in the Interim Constitution'. In The Constitution of South Africa from a Gender Perspective, ed. S. Liebenberg, 157-66. Cape Town: Community Law Centre, University of the Western Cape.

Ntsebeza, Lungisle, 1999. Land Tenure Reform, Traditional Authorities and Rural Local Government in Post-apartheid South Africa. Research Report No. 3. Cape Town: Programme for Land and Agrarian Studies, University of the Western Cape.

Ntsebeza, Lungisile, 2003. 'Structures and Struggles of Rural Local Government in South Africa: the Case of Traditional Authorities in the Eastern Cape'. PhD thesis. Rhodes University.

Ntsebeza, Lungisile, 2004. 'Democratic Decentralisation and Traditional Authority: Dilemmas of Land Administration in Rural South Africa'. European Journal of Development Research, 16 (1): 71-89.

Odgaaard, Rie, 2003. 'Scrambling for Land in Tanzania: Processes of Formalisation and Legitimisation of Rights'. In Securing Land Rights in Africa, eds Tor A. Benjaminsen and Christian Lund, 71-88. London: Frank Cass.

Okoth-Ogendo, H.W.O., 1989. 'Some Issues of Theory in the Study of Tenure Relations in African Agriculture'. Africa, 59 (1): 6-17.

Okoth-Ogendo, H.W.O., 2002. 'The Tragic African Commons: A Century of Expropriation, Suppression and Subversion'. Occasional Paper No. 24. Cape Town: Programme for Land and Agrarian Studies, University of the Western Cape.

Oomen, Barbara, 2000. " "We Must Now Go Back To Our History": Retraditionalisation in a Northern Province Chieftaincy'. African Studies, 59 (1): 71-95.

Oomen, Barbara, 2005. Chiefs in South Africa. Law, Power and Culture in the Post-Apartheid Era. Oxford/Pietermaritzburg/New York: James Currey/University of KwaZuluNatal Press/Palgrave.

Peires, J.B., 2000. 'Traditional Leaders in Purgatory. Local Government in Tsolo, Qumbu and Port St Johns, 1990-2000'. African Studies, 59 (1): 97-114.

Peters, Pauline, 2002. 'The Limits of Negotiability: Security, Equity and Class Formation in Africa's Land Systems'. In Negotiating Property in Africa, eds K. Juul and C. Lund, 45-66. Portsmouth, NH: Heinemann.

Peters, Pauline, 2004. 'Inequality and Social Conflict Over Land in Africa'. Journal of Agrarian Change, 4 (3): 269-314.

Reader, D.H., 1966. Zulu Tribe in Transition. The Makhanya of Southern Natal. Manchester: Manchester University Press.

Republic of South Africa, 2004. The Communal Land Rights Act no. 11 of 2004. Cape Town: Government Gazette.

Royston, Lauren, 2004. 'Barking Dogs and Building Bridges: A Contribution to Making Sense of Hernando de Soto's Ideas in Our Context'. Paper presented to workshop on 'The Perpetual Challenge of Informal Settlements', Wits University, 8-10 November 2004.

Sansom, B., 1974. 'Traditional Economic Systems'. In The Bantu-Speaking Peoples of Southern Africa, ed. W.D. Hammond-Tooke, 135-76. London: Routledge Kegan Paul.

Sawadogo, J.-P. and V. Stamm, 2000. 'Local Perceptions of Indigenous Tenure Systems: Views of Peasants, Women and Dignitaries in a Rural Province of Burkino Faso'. Journal of Modern African Studies, 38 (2): 279-94.

Schapera, Isaac, 1955. A Handbook of Tswana Law and Custom. London: Oxford University Press.

Shackleton, Sheona, Charlie Shackleton and Ben Cousins, 2000. 'The Economic Value of Land and Natural Resources to Rural Livelihoods. Case Studies from South Africa'.

(C) 2007 The Author.

Journal compilation (C) 2007 Blackwell Publishing Ltd, Henry Bernstein and Terence J. Byres. Journal of Agrarian Change, Vol. 7 No. 3, July 2007, pp. 281-315. 
In At the Crossroads. Land and Agrarian Reform in South Africa into the 21st Century, ed. Ben Cousins, 35-67. Cape Town: Programme for Land and Agrarian Studies, University of the Western Cape and National Land Committee.

Shipton, Parker, 1988. 'The Kenyan Land Tenure Reform: Misunderstandings in the Public Creation of Private Property'. In Land and Society in Contemporary Africa, eds R.E. Downs and S.P. Reyna, 91-135. Hanover, NH: University of New England Press. Shipton, Parker and Mitzi Goheen, 1992. 'Understanding African Landholding: Power, Wealth, and Meaning'. Africa, 62 (3): 307-25.

Sibanda, Sipho, 2004. 'Principles Underpinning the Communal Land Rights Bill 2001'. In National Land Tenure Conference. Finding Solutions, Securing Rights, eds Michael Roth, Vuyi Nxasana, Sipho Sibanda and Teresa Yates, 156-84. Durban: LexisNexis Butterworths.

Sithole, Mpilo, 2004. 'Communal Land Tenure Versus Individual Housing Tenure? Working Together in Housing Provision'. Paper presented to the National Rural Housing Symposium, Johannesburg, 13 May 2004.

Sjaastad, Espen, 2003. 'Trends in the Emergence of Agricultural Land Markets in Sub-Saharan Africa'. Forum for Development Studies, 30 (1): 5-28.

Small, Janet, 1997. 'Women's Land Rights: A Case Study from Northern Transvaal'. In Women, Land and Authority: Perspectives from South Africa, ed. Shamin Meer, 45-52. Cape Town: David Philip.

Small, Janet and Harold Winkler, 1992. Botho Sechabeng. A Feeling of Community. Johannesburg: Transvaal Rural Action Committee.

Thorp, Lisa, 1997. 'Access to Land: A Rural Perspective on Tradition and Resources'. In Women, Land and Authority: Perspectives from South Africa, ed. Shamin Meer, 35-44. Cape Town: David Philip.

Turner, Stephen, 1999. 'Land Rights and Land Administration in the Herschel and Maluti Districts, Eastern Cape'. Occasional Paper No. 10. Cape Town: Programme for Land and Agrarian Studies, University of the Western Cape.

Walker, Cherryl, 1997. 'Cornfields, Gender and Land'. In Women, Land and Authority: Perspectives from South Africa, ed. Shamin Meer, 55-73. Cape Town: David Philip.

Walker, Cherryl, 2002. 'Panel Discussion: Ensuring Women's Land Rights. Moderator's Comments'. Paper presented to a World Bank Regional Workshop on Land Issues in Africa and the Middle East, Kampala, Uganda, 29 April-2 May 2002.

Whitehead, Ann and Dzodzi Tsikata, 2003. 'Policy Discourses on Women's Land Rights in Sub-Saharan Africa: the Implications of the Return to the Customary'. Journal of Agrarian Change, 3 (1/2): 67-112.

Woodhouse, Philip, 2003. 'African Enclosures: A Default Mode of Development'. World Development, 31 (10): 1705-20.

Woodhouse, Philip, Henry Bernstein and David Hulme, 2000. 'Africa's "Wetlands in Drylands". From Commons to Enclosures?'. In African Enclosures? The Social Dynamics of Wetlands in Drylands, eds Philip Woodhouse, Henry Bernstein and David Hulme, 1-28. Oxford: James Currey.

Ziqubu, N., T. Cousins and D. Hornby, 2001. 'Using Local Practices and Records to Secure Individual Tenure Rights in Common Property Situations'. Paper presented to the National Land Tenure Conference, Durban, 26-30 November 2001.

(C) 2007 The Author.

Journal compilation (c) 2007 Blackwell Publishing Ltd, Henry Bernstein and Terence J. Byres. Journal of Agrarian Change, Vol. 7 No. 3, July 2007, pp. 281-315. 